\title{
ON SOME PROPERTIES OF ACRONYMS USED IN KOREAN
}

\author{
Anna BOROWIAK, PhD \\ Department of Korean Studies \\ Institute of Linguistics \\ Adam Mickiewicz University \\ al. Niepodległości 4 \\ Poznań, Poland \\ annaboro@amu.edu.pl
}

\begin{abstract}
Abbreviation process in Korean applies to both lexical and grammatical units (cf. Borowiak 2015). This article however focuses only on one type of the former, namely acronyms. The formations in question are created in the lingual process, which could be called acronymization and are a convenient means of expression widely used in various fields of contemporary civilization such as science and technology, economy and public life, media, marketing etc. Despite their undeniable popularity the subject of acronymology is given relatively little attention in relevant literature, which concentrates mainly on morpheme-based word-formation and thus downplays acronyms as being e.g. unpredictable 'non-rule governed innovations' (cf. Bauer 2001). The $20^{\text {th }}$ century however, as Szadyko (1997: 127) points out, belongs to acronyms - that is why the subject definitely deserves more attention.

The aim of this article is to identify, analyze and classify acronyms used in Korean. Abbreviations of this particular type, as this paper will attempt to show, although rarely and rather briefly discussed, are in fact extremely numerous in Korean language. Taking into consideration their number and variety the attempt to classify them according to origin, fields of usage, lexical meaning and familiarity, the method of formation, graphemic form and the type of founding constituents is made.
\end{abstract}


Keywords: Korean language, lexical abbreviation, acronym, acronymization, acronymology, classification criteria

\section{한국어에서 사용되는 두문자어의 일부 속성(屬性)에 관한 고찰}

논문초록: 한국어에서의 축약 과정은 각각 어휘적인 단위와 문법적인 단위에 의해서 이루어진다(Borowiak 2015 참조). 그러나 본 연구는 전자의 방법 중 하나인 두문자어(acronym)에만 초점을 맞춘다. 논의하고자 하는 어휘적인 단위의 축약은 두문자화 (頭文字化, acronymization)라고 명명할 수 있는 언어 과정에 의해 형성되며, 현대 사회의 여러 분야, 즉 과학과 기술, 경제와 공적 생활, 대중 매체, 마케팅 등의 분야에서 불가결하고 편리한 표현 수단으로 사용된다. 이러한 두문자어의 부정할 수 없는 대중성에도 불구하고 두문자론(頭文字論, acronymology)의 주제는 대체로 형태소에 중심을 두는 조어법에 있어서 상대적으로 적은 관심을 받고 있다. 또한 두문자어를 예측이 불가한 '비규칙적으로 규정된 혁신'(Bauer 2001 참조)으로 여기고 경시한다. 그러나 Szadyko (1997: 127)가 지적한 바와 같이 '20세기는 두문자어의 세기이다.' 따라서 이 분야의 연구에 더욱 주목할 만한 가치가 있음을 밝힌다.

본 연구의 목적은 한국어에서 사용되는 두문자어를 찾아내고, 분석·분류하는 데에 있다. 본고에서는 매우 드물고 간략하게만 다루어지는 이 독특한 형태의 축약형이 실제로는 한국어에 수적으로 대단히 많이 존재함을 제시하고자 한다. 그리하여 두문자어의 수와 다양성을 염두에 두고 어원, 사용 분야, 어휘적인 의미와 친숙함, 형성 방법, 서기소(書記素)의 형태 및 구성 요소의 특성에 따른 분류를 시도할 것이다.

주제어: 한국어, 어휘적 축약, 두문자어, 두문자화 (頭文字化), 두문자론 (頭文字論), 분류기준

\section{O NIEKTÓRYCH WLASNOŚCIACH AKRONIMÓW UŻYWANYCH W JĘZYKU KOREAŃSKIM}

Streszczenie: Proces abrewiacji w języku koreańskim dotyczy zarówno jednostek leksykalnych, jak i gramatycznych (por. Borowiak, 2015). Niniejszy artykuł skupia się jednak tylko na jednym rodzaju tych pierwszych, a mianowicie na akronimach. Wspomniane formacje powstają w procesie językowym, który można nazwać akronimizacja i są wygodnym środkiem ekspresji szeroko stosowanym w różnych dziedzinach współczesnej cywilizacji, takich jak nauka i technika, ekonomia, życie publiczne, media, marketing itp. Pomimo swej 
niezaprzeczalnej popularności, zagadnieniu akronimologii poświęca się $\mathrm{w}$ literaturze przedmiotu stosunkowo niewiele uwagi. Wynika to zapewne z faktu, iż koncentruje się ona głównie na słowotwórstwie, opartym na analizie morfemów jako jednostek składowych i w związku z tym bagatelizuje akronimy, traktując je jako nieprzewidywalne „innowacje, nieoparte na regułach” (por. Bauer, 2001). Jednakże, jak wskazuje Szadyko (1997: 127), wiek XX należy do akronimów, dlatego też temat ten zasługuje na zdecydowanie większą uwagę. Celem niniejszej pracy jest wskazanie, przeanalizowanie oraz sklasyfikowanie akronimów używanych w języku koreańskim. Abrewiacje tego właśnie typu, choć rzadko i raczej pobieżnie omawiane $\mathrm{w}$ publikacjach poświęconych koreańskiemu słowotwórstwu, w języku koreańskim bardzo często występują. Biorąc pod uwagę ich liczbę oraz różnorodność, podjęto próbę sklasyfikowania ich na podstawie takich kryteriów, jak: pochodzenie, obszar zastosowania, rozpoznawalność, sposób tworzenia, forma grafemiczna oraz rodzaj elementów składowych.

Słowa kluczowe: język koreański, abrewiacja leksykalna, akronim, akronimizacja, akronimologia, kryteria klasyfikacji

\section{Introductory Remarks}

The abbreviation of various linguistic units such as words, syntagmas and even whole sentences is nothing new. Szadyko (1997: 116) and Podracki (1999: 11) explain that the tendency to economize in expression is presumably as old as handwriting itself, since it was already known and frequently used in Roman and Medieval Times. Algeo (1973: 269) assumes that it can be much older and date back even before the Roman Times. Cannon (1989) and Asher et al. (1994) highlighting its long history give examples from Hebrew and Latin - MILH from 'Mi Iolh Lnv Hshmilh' meaning 'Who shall go up for us to heaven?' and INRI from 'Jesus Nazarenus Rex Judaeorum' meaning 'Jesus the Nazarene, King of the Jews' respectively. Asher et al. (1994: 80) also impart that over the centuries, even whole sentences have been reduced, exemplifying it with French RSVP from 'réspondez s'il vous plaît'. 
Despite its long history, the habit of shortening of words and phrases started to spread in Europe only at the beginning of the $20^{\text {th }}$ century, especially during the First World War, which was under the influence of the press and war messages (cf. Czarnecka \& Podracki 1995: 9). The usage of systematically created initialisms began however, as Cannon (1989) points out, with World War II and, as a consequence, led to the formation of new items, that are not always formal. Further expansion of abbreviated forms after 1945 is basically recorded all around the world.

Even though lexical abbreviations such as clippings, blends, and acronyms are frequently coined and extensively used, it is the acronym to which the $20^{\text {th }}$ century belongs. This is the very reason why Szadyko (1997: 127) calls the 20 century 'the era of acronyms'. Their growing popularity however was also noticed by Algeo (1980: 270-271) who in order to signal the considerable number of acronyms and alphabetisms being used between 1930's and 1970's by the US administration introduces the term 'the alphabet soup'. He also observes, on the basis of entries in the dictionaries of acronyms, the effects of so-called 'acronymania' defined by Collins Online Dictionary as 'a great enthusiasm for creating acronyms'.

Nonetheless not only linguists but also press noticed the phenomenon of the increase in the number of acronyms. Time magazine in the article titled 'The Agonies of Acronymania' (10 July 1970) refers to extensively coined and used acronyms such as PAMIPAC (Personnel Accounting Machine Installation-Pacific Fleet). William Safire - The New York Times' reporter is convinced that 'the recent state of acronymania (...) can be combated only by resolute ridicule' and in his article from 24 February 2002 he makes fun of bizarre acronyms formed by the Pentagon, which he calls 'professional acronym creators' describing one of them as somebody, who has 'achieved acronymic immortality' since he came up with an acronym PATRIOT which stands for 'Providing Appropriate Tools Required to Intercept and Obstruct Terrorism'. $\mathrm{He}$ also refers to a cartoon in Punch Magazine, which showed marchers under a banner titled COCOA - the Council to Outlaw Contrived and Outrageous Acronyms.

Despite the undeniable omnipresence of acronyms in 
various aspects of our everyday life, although not always welcomed in formal registers of the language, morpheme-based word-formation concentrated on morphemes as word components, discusses the subject of acronyms along with clippings and blends rather briefly.

The tendency to focus basically on regular 'rule-governed processes' like derivation and compounding was noticed by Cannon (1989: 119). As an example of words that are not necessarily bound by such rules since their crucial dependence on orthography he gives initialisms. The lack of predictability is the very reason why Bauer (2001) and other linguists downplay those 'non-rule governed innovations'. Algeo (1980: 272) however remarks that of the various kinds of shortenings the largest subgroup are forms such as 'acronyms, alphabetisms and the like'. Asher et al. (1994: 80) while describing the 'Alphabet-based Wordcreation' remark that acronyms are 'a vigorous part of modern vocabulary expansions' and that they 'are more the product of word-creation than of word-formation'. They even perceive them as 'orthographically conceived items' with 'a necessary place in the vocabulary' (cf. p. 80). Furthermore, the authors also consider acronyms to be 'the most creative, freewheeling creations in vocabulary today'. That apparent irregularity of forms of acronyms not only opens the door for creativity and playfulness but also for unconventionality, which to Fandych (2008: 117) is one of the reasons of their unprecedented popularity and productivity (in English in recent decades). The great number of dictionaries of such 'consciously made' items proves the utility of initialisms and reflects the dynamic nature of word-formation in rich forms, which sheds a light on the overall process of vocabulary expansion - as Asher et al. (1994: 81) further elaborate.

The aim of this research is to identify, analyze and classify acronyms used in Korean. Despite their ubiquity and the benefits from their usage such as to facilitate memorization of long terms or to adopt the names of foreign provenance in question in the target language without the necessity of translation (e.g. NATO, GDP etc.) the subject of acronymy is hardly taken up and discussed by 
Anna BOROWIAK: On Some Properties of Acronyms...

Korean linguists, despite the fact, that acronyms have already established their position in mass media and everyday life and thus definitely deserve greater attention.

\section{An Acronym - Different Approaches to the Definition}

Acronym is a kind of abbreviation, which is to act as shorthand for long terms especially when concerns the terms frequently referred to. The term 'acronym' is a coinage from Greek 'akros' meaning 'tip' and 'ónyma' meaning 'name' (cf. Online Dictionary Reference). The technical term was coined by Bell Laboratories' researcher and its first known use was in 1943 (cf. Baum 1962: 48, Algeo 1973: 272, Merriam-Webster Online Dictionary and others). Nevertheless Cassidy (1993: 400) referring to supplement to the Oxford English Dictionary from 1972 indicates that the term 'acronym' had been in oral use before 1943 .

Although there is no doubt as to the etymology of the term itself, defining it appears to be somewhat difficult taking into account its similarities to other words constituting a large group of abbreviations. There is no clear classification of abbreviated forms, which undoubtedly is caused by the lack of strict definitional criteria and the semantic intransparency of the forms in question, which leads to the overlapping of their categories and confusion. That is why there seem to be no consensus on what an acronym really is.

The dictionary definitions of the term 'acronym' presented in both online and traditional dictionaries define it with different degrees of precision - as shown in the below Table 1. Although lexicographers do list acronym as a headword instead of defining it, they also put a note to check for another headword namely abbreviation. 
International Journal of Korean Humanities and Social Sciences

Table 1 . The dictionary definitions of an 'acronym'

\begin{tabular}{|c|c|}
\hline Dictionary & The definition of an 'acronym' \\
\hline $\begin{array}{l}\text { Online } \\
\text { Etymology } \\
\text { Dictionary }\end{array}$ & a word formed from the first letters of a series of words \\
\hline $\begin{array}{l}\text { Merriam } \\
\text {-Webster } \\
\text { Online } \\
\text { Dictionary }\end{array}$ & $\begin{array}{l}\text { a word (as NATO, radar, or laser) formed from the initial letter } \\
\text { or letters of each of the successive parts or major parts of a } \\
\text { compound term; also an abbreviation (as FBI) formed from } \\
\text { initial letters - initialism }\end{array}$ \\
\hline Dictionary.com & $\begin{array}{l}\text { 1) a word formed from the initial letters or groups of letters of } \\
\text { words in a set phrase or series of words and pronounced as a } \\
\text { separate word, as Wac from Women's Army Corps, OPEC from } \\
\text { Organization of Petroleum Exporting Countries, or loran from } \\
\text { long-range navigation } \\
\text { 2) a set of initials representing a name, organization, or the } \\
\text { like, with each letter pronounced separately; an initialism } \\
\text { 3) an acrostic }\end{array}$ \\
\hline $\begin{array}{l}\text { Müldner } \\
\text {-Nieckowski } \\
(2007: 8-9)\end{array}$ & $\begin{array}{l}\text { resultant forms (which are proper names or concepts) formed } \\
\text { from initial components of a phrase such as letters, speech } \\
\text { sounds (phones) or syllables (not always all of them) and } \\
\text { which do function or can function as an independent word }\end{array}$ \\
\hline
\end{tabular}

All of the above definitions relate to the structure of acronyms, however only Dictionary.com mentions its pronounceablity as a word, and only Müldner-Nieckowski refers to the fact that they do or can function as autosemantic words. ${ }^{1}$

\footnotetext{
${ }^{1}$ Nevertheless not all lexicographic works have the term 'acronym' as their entries. '응용언어학 사전' by 박경자 et al. (2001), 'Encyklopedia Językoznawstwa Ogólnego' by Polański et al. (2003) and 'Encyklopedia Języka Polskiego' by Urbańczyk et al. (1999) and can serve as examples here. Even though the first one gives definitions of specialist terms such as 'developmental interdependence hypothesis', 'free morpheme constrains' or terms related to word-formation field such as 'affix' or 'prefix' neither the term 'acronym' nor 'abbreviation' in nowhere to be found. The two just cited encyclopedias do give examples of acronyms while enumerating the kinds of abbreviation referred to as shortenings - pronounced as words and those pronounced as individual letters - alphabetisms or initialismsm though they do not use the term either (cf. 2003: 537, 1999: 351 respectively).
} 
Not only lexicographers but also linguists tried to define the term 'acronym', nevertheless some of their proposals do not eliminate ambiguity concerning the definition. Stockewll \& Minkova (2001:7) for example perceive acronyms 'as a special type of blend.' adding that a 'typical acronym' takes the first sound from each of several words and makes a new word from those initial sounds.' If it is pronounced as a word, it is treated as a true acronym, however on the convenience pronunciation' sake, if e.g. apart form the first consonant the first vowel is also taken, this kind of shortening is described as being 'half-way between blends and acronyms'. On the basis of their definition, one can ask a question: 'How a unit being included into the class of blends can at the same time be 'half-way between' themselves and blends?'

Baum (1962: 49-50) on the other hand distinguishes acronyms from blends on the basis of the degree of shortening of their constituents. The examples of acronyms given by Haller \& Macris (1968: 207) suggest that clippings as ad (from 'advertisement') as well as blends (e.g. brunch form 'breakfast' and 'lunch') were also included here.

Certain discrepancies not only concern the definition of an acronym but also the classification of shortenings as well. Cannon (1989: 106) uses initialism as an inclusive term for abbreviations and acronyms - the categories of shortening, while for Rúa (2004) the term initialism is a superordinate comprising both acronyms and alphabetisms. Fandrych (2008) on the other hand uses the term acronym to cover both pronounceable formations such as NATO and those with letter-by-letter pronunciation, namely initialisms.

In the face of a growing number of acronyms and the dictionaries dedicated to them, Algeo (1973: 271) asks several very important questions concerning the nature of acronyms, some of which were answered by Cannon (1989: 106), who stipulates two conditions of initialisms - an inclusive term for abbreviations and acronyms, as already mentioned:

(i) except of an infrequent one or two letters inserted for orthographic purposes every constituent in the initialism must have a known lexical source (excluding e.g. items like 'A-line', because A has no such source)

(ii) no constituent word in the source can be preserved intact. 
As one can see from the above criteria the lexical structure of the source word and the fact that all constituents must be reduced to some extent decide whether a word is an initialism or not. Rúa (2004: 120) remarks that these criteria can be satisfied by some blends as well, she gives no examples though. According to her research central acronyms can be written in capitals (e.g. SALT 'Strategic Arms Limitation Talks'), less central items include two initials per source word taken from more than one word or the choice of letters which are not initials, the bigger combination the less central item is (e.g. BORAX from 'BOiling ReActor eXperiment'), peripheral items are a combination of initialized and clipped constituents (e.g. Algol/ ALGOL from 'ALGOrythmic Language); initials and full constituents (e.g. LIMEAN from 'London Interbank MEAN rate'), initials and chemical symbols or formulae (e.g. $\mathrm{Na}$ - 'sodium'), or words which lack original expression (e.g. 'qwerty/ QWERTY')(cf. p. 125-6).

There are several approaches to the classification of acronyms, some of them are as follows:

(i) pure and impure acronyms (Baum 1962);

(ii) acronym, mesonym, ouronym (Haller \& Marcis 1968);

(iii) letter acronyms (pronounced as words or as individual letters), syllable acronyms and acronyms of mixed structure (Paruch 1970, Czarnecka et al. 1995, Müldner-Nieckowski 2007 and others);

(iv) letter-naming type and letter-sounding type (Kreidler 1978);

(v) acronyms of the 1s, $2^{n d}, 3^{n d}, 4^{\text {th }}$ order (Algeo 1978);

(vi) central, less central and peripheral acronyms (Rúa 2004).

On the basis of books on Korean language both written and published in South Korea one can remark that the inquiry of acronymy in Korean is basically nonexistent. That is why finding in-depth or elaborate analysis on this subject is nearly impossible. 
General reference books on Korean, which take up the subject of word-formation discuss it in a brief manner and fail to mention the existence of acronyms in Korean (cf. 이승희 1955, 최현배 1961, 허웅 1983, 고영근 1991, 남기심 \& 고영근 2006, 나찬연 2007 etc.). Monographs entirely devoted to word-formation issues focus only on traditional morpheme-based word-formation processes and also fail to mention their existence (cf. 시정군 1994, 김창섭 1996, 김정은 2000, 최규일 2009 etc.).

As far as lexicographic works are concerned, in few dictionaries the term 'acronym' is not listed as an entry although its definition (without the term being used however) constitute the second part of the definition of an 'abbreviation' (Kor. 준말) as in 이희승 (1982) or 양주동 (1988).

Table 2. The definition of an 'abbreviation' in Korean dictionaries

\begin{tabular}{|c|c|}
\hline Dictionary & Definition \\
\hline $\begin{array}{l}\text { 이희승 } \\
\text { (1982: } \\
3400)\end{array}$ & $\begin{array}{l}\text { 1) a shortened word coming from a word, which consists of } \\
\text { two or more syllables; } \\
\text { 2) a word created by taking only the first letter from words } \\
\text { and conveniently used as a kind of a symbol e.g. U.S.A. }\end{array}$ \\
\hline $\begin{array}{c}\text { 양주동 } \\
\text { (1988: 566) }\end{array}$ & $\begin{array}{l}\text { 1) shortening of words or a shortened word e.g. 새새(form } \\
\text { 사이사이 meaning 'intervals, spaces, gaps') } \\
\text { 2) a word created by combining first letters from words or a } \\
\text { phrase etc. and used as a symbol instead of them e.g. 'The } \\
\text { Bank of Korea' - Kor. 한은, M.P. - Kor. 엠피 }\end{array}$ \\
\hline
\end{tabular}

On the basis of given examples the definition proposed by 양주동 appears to be more inclusive than the one by 이희승 since it also includes words created from compounds (and not only syntagmas) as in 'The Bank of Korea' - 한은 (an abbreviated form from a compound noun 한국은행, which in fact is written a single word according to 표준국어 대사전 and thus can be treated as one word). Although the definition does not say so, the given example confirms that acronymy applies also to whole syllables and not only to first letter of each word, as in just cited '한은'.

홍순성 (1993: 153-5) apart from defining acronyms as 
words formed from initial letters of words, divides them on the basis of their morphological structure into those created from two words e.g. '한일' (from '한국 일본' meaning 'Korea and Japan') and those formed from a compound word e.g. '한은' (from '한국은행'). Nevertheless both formations not only are morpheme abbreviations (and not letter ones) but also seem to come from two words, although the second one comes from the abbreviation of a compound built from nouns such as 'Korea' and 'bank' (Kor. '한국' and '은행' respectively) meaning 'The Bank of Korea'.

김진우 (1985: 136) to the above definitions of an acronym, adds that an acronym is a word built from first letters or first syllables, which became a requirement for a word to become an acronym in Korean. 이지양 (1993: 10) notices however that there are almost no examples of new words built from the first letters in Korean, by which he means in Hangeul. He provides no examples of those though. Also 이재현 (2005: 380-381) convinces that in Korean initial abbreviation of Hangeul words does not take place. ' $\mathrm{O}$ 人' (from 연세대학교) - is a kind of example difficult to find both in spoken and written Korean he elaborates. Even if ' $O$ 入' would be written it would still be read as [ieung] (Kor. '이응') and [siot] (Kor. '시옷') respectively and consequently only the graphic form would be reduced, the pronunciation however would be much prolonged (4 syllables instead of 2 letters). 송철의(2008: 85) notices that although the 'Korean Orthography' (Kor. 한글 맞춤법) uses the term 'abbreviation' (Kor. 준말), it is not properly defined. In this context he refers to lexical units such as '노동조합' meaning 'labor union' reduced to '노조' and United States of America shortened to 'U.S.A.' and even though only the latter is called an 'acronym', the author is convinced that it would not be unreasonable to call the former the same term too, despite the fact that their features are not homogenous (cf. p. 89). He explains that the former cannot be recognized as a blend since blends are formed from the fist syllable of one word and the back part of another one, while '노조', as he explains, is formed from the first syllable of 
both words. ${ }^{2}$

이지양 (1993: 10) convinces that acronyms along with blends have a special place among words which are the outcome of abbreviation. Nevertheless, the examples of both kinds of abbreviations that he provides are very similar and only on their basis, it is difficult to grasp the difference between them. Since '연개' meaning 'smog' from '연기' (smoke) and '안개' (fog) is treated as a blend, while ‘국교' from '국민학교' meaning 'an elementary school' as an acronym. One can only presume that the difference lays in the fact that the second one is a compound, which could confirm that 이지양 perceives as acronyms words which, could be also analyzed as complex clippings. He also stipulates that 'acronyms are words formed from the first letters or (only) the first syllables and are used as a sign (or a symbol).

In books on Korean published outside of South Korea, the subject of acronymy is given some attention - still too little, since the reference to them is limited to literally short paragraphs. Although Lee \& Ramsey (2000), Miho \& Kwak (2008) and others give a brief discussion on word-formation related topics, they do not mention acronymy. Lee \& Ramsey (2011: 305) however discussing vocabulary trends in Contemporary Korean such as native neologisms and loans, in section devoted to 'other vocabulary trends', which 'now characterize the lexicon', by which the authors mean abbreviations, they make a short notice of acronyms. They define them as 'East-Asian type of acronym[s]', which combine the first syllables of the name or term's constituent elements. We can find 3 examples such as '공동 위원회' shortened to '공위' and '노동조합' abbreviated to '노조', meaning 'joint commission' and 'labor union' respectively.

On the basis of the above considerations, one can confirm the variety of definitions and classifications of acronyms. Nevertheless in this article the traditional classification of acronyms proposed by Paruch (1970: 10-11), Czarnecka \& Podracki (1995: 13-4), Müldner-Nieckowski (2007:8-9) and others will be followed. As a consequence acronyms will be divided into 4 groups according

\footnotetext{
${ }^{2}$ It is worth to mention however that blends can also be built from the beginning of each word as it is in e.g. cyborg built from cybernetic and organism. Which makes the definition not transparent enough.
} 
to their constituents' properties, which can be either initial individual letters or first syllables of words. Those formed from initial letters will be divided according to their pronunciation into those pronounced as words and those pronounced as individual letters. Apart from the letter and syllable acronyms there are also those of mixed structure formed from both types.

\section{Acronyms Used in Korean}

Algeo (1973: 270) remarks that any alphabetical writing system invites the making of acronyms. Giving the fact that Korean does have an alphabetic writing system, the question concerning the possibility to form this particular kind of lexical abbreviation should be easy to answer. However, given the differences in syllable structure of Hangeul and other alphabetic writing systems, the question may not be that easy to answer. Even though syllables in Korean, unlike in other alphabetic writing systems, form a sort of blocks corresponding to syllables they also reveal some restrictions e.g. they do not allow more than one consonant in the syllableonset, which makes the Korean syllable structure unique.

As mentioned above, acronymy is not the subject Korean linguists discuss. If they do refer to acronyms at all, they do it very briefly. Usually three terms are used to describe them, namely:

$$
\text { 머리글자말 (cf. 홍순성 1993: 153, 이재현 2005: 380), }
$$

(ii) 두문자어 (cf. 황명권 \& 정도헌 2011, 최경은 2005: 8), (iii) 두자어 (cf. 이지양 1993: 10-11, 송철의 2008: 89).

이재현 (2005: 382) notices that a concept corresponding to English term 'acronym' does exist in Korean, but rather than calling it '머리글자말' it would be appropriate to call them ‘머리음절말' or ‘두음절말', which can be translated as 'syllable acronym'. 
Anna BOROWIAK: On Some Properties of Acronyms...

\subsection{Criteria of Classification of Acronyms}

Acronyms, as this paper will attempt to show, are extremely numerous in Korean language. On the basis of relatively small data, gathered for the purpose of this research, they can be classified according to the following criteria:
(i) Origin,
(ii) Fields of usage,
(iii) Conveyed meaning,
(iv) Lexical familiarity,
(v) Method of formation,
(vi) Graphemic form,
(vii) Type of founding constituents.

Each of the above criterion will be discussed in the following sections of this paper.

\subsubsection{Origin}

Numerous acronyms used in Korean language can be largely divided into two groups on the basis of their origin, namely:

(i) the ones of foreign (Western) affiliation (see ex. 1.1) and

(ii) those coined in Korean (see ex. 2.2).

Acronyms from the first group are usually direct borrowings mainly from English and used as internationalisms. Among them are those: a) written only in Roman script, b) written in Roman script or transcribed into Korean, c) written in Roman script or translated into Korean.

The second group can be further subdivided into acronyms, which, are:

(i)made on the basis of English translation of Korean names, 
(ii) both partially Romanized and partially translated names,

(iii) made on the basis of Hangeul (which are in fact SinoKorean words). ${ }^{3}$

\section{(3.1) Direct borrowings}

A. Written in Roman Alphabet
a) LED (light-emitting diode)
b) IC (integrated circuit)
c) JCT (junction)

B. Written in Roman or Korean alphabet
a) UNESCO (The United Nations Educational, Scientific and Cultural Organization) - Kor. 유네스코
b) NATO (North Atlantic Treaty Organization) - Kor. 나토 c) NASA (National Aeronautics and Space Administration) - Kor. 나사
d) IQ (intelligence quotient) - Kor. 아이큐
e) FM (frequency modulation) - Kor. 에프 엠
f) LPG (liquefied petroleum gas) - Kor. 엘피지
g) USB (universal serial bus) - Kor. 유에스비
h) GATT (the General Agreement on Tariffs and Trade) - Kor. 가트
i) TOEFL (Test of English as a Foreign Language) - Kor. 토플

C. Written in Roman script or translated into Korean ${ }^{4}$

\footnotetext{
${ }^{3}$ Hangeul-based acronyms are referred to as 'East-Asian type of acronym[s]' (cf. Lee \& Ramsey, 2011) or 'syllable acronyms' (cf. 이재현, 2006: 382). Nevertheless due to their close resemblance to blends, caused by the lack of strict definitional criteria and thus inability to differ these two categories of lexical abbreviations in an unambiguous way they will not be discussed here. Nevertheless those formations are briefly referred to in the section 3.6. of this article while addressing the question of their graphemic form.

${ }^{4}$ Although Korean version does exist shorter version in used more frequently.
} 
Anna BOROWIAK: On Some Properties of Acronyms...
a) GPS (Global Positioning System) - Kor. 지피에스
b) SUV (Sport Utility Vehicle) - Kor. 스포츠 실용차
c) EU (European Union) - Kor. 유럽연합
d) FTA (Free Trade Agreement) - Kor. 자유 무역 협정
e) CEO (chief executive officer) - Kor. 최고 경영자, 시이오
f) ESL (English as a Second Language) - Kor. 제2언어로서의 영어
g) FAQ (frequently asked questions) - Kor. 자주 묻는 질문
h) Q\&A (question and answer) - Kor. 문답
i) $\quad \mathrm{A} / \mathrm{S}$ (after service) - Kor. 애프터 서비스
j) YMCA (Young Men's Christian Association) - Kor. 와이엠시에이, 기독교 청년회

(3.2) Coined in Korean

A. English translation of Korean names followed by acronymization
a)
대한민국 $\rightarrow$ Republic of Korea $\rightarrow$ ROK
b)
비무장 지대 $\rightarrow$ Demilitarized Zone $\rightarrow \mathrm{DMZ}$
c)
교육부 $\rightarrow$ Ministry of Education $\rightarrow \mathrm{MOE}$
d) 국방부 $\rightarrow$ Ministry of National Defense $\rightarrow$ MND
e) 국방정보본부 $\rightarrow$ Korean Defense Intelligence Agency $\rightarrow$ KDIA
f) 세누리당 $\rightarrow$ New Frontier Party $\rightarrow$ NFP
g) 새정치민주연합 $\rightarrow$ New Politics Alliance for Democracy $\rightarrow$ NPAD
h) 한국 증권 거래소 $\rightarrow$ Korean Stock Exchange $\rightarrow$ KSE
i) 한국 외환 은행 $\rightarrow$ Korea Exchange Bank $\rightarrow$ KEB
j) 기업은행 $\rightarrow$ Industrial Bank of Korea $\rightarrow$ IBK
k) 한국정보보호진흥 $\rightarrow$ Korea Information Security Agency $\rightarrow$ KISA
1) 국제협력단 $\rightarrow$ Korea International Cooperation 
International Journal of Korean Humanities and Social Sciences

Agency $\rightarrow$ KOICA

m) 대한항공 $\rightarrow$ Korean Air Lines $\rightarrow$ KAL

n) 서울방송 $\rightarrow$ Seoul Broadcasting System $\rightarrow$ SBS

B. Partial Romanization and partial translation of Korean names followed by acronymization

a) 신한은행 (shinhan eunhaeng) $\rightarrow$ Shinhan Bank $\rightarrow$ SHB

b) 문화방송 (munhwa bangsong) $\rightarrow$ Munhwa Broadcasting Corporation $\rightarrow \mathrm{MBC}$

c) 경희대학교 (kyunghee daehakgyo) $\rightarrow$ Kyung Hee University $\rightarrow$ KHU

d) 건국대학교 (konkuk daehakgyo) $\rightarrow$ Konkuk University $\rightarrow \mathrm{KU}$

e) 한국외국어대학교 (hankuk eogugeo daehakgyo) $\rightarrow$ Hankuk University of Foreign Studies $\rightarrow$ HUFS $^{5}$

One can observe from the semantic point of view that for some acronyms the resultant forms of English translation of Korean forms do not always convey the exact meaning as the Korean source forms. In other words, the meaning of an acronym does not completely correspond with the Korean name. This is of course a matter of translation and not the aconymy itself (see ex. 3.3).

(3.3) a) SNU (Seoul National University) - Kor. 서울대학교 (literal translation 'Seoul University')

b) KBS (Korean Broadcasting System)

- Kor. 한국방송공사 (literal translation 'Korean Broadcasting Company/ Public Corporation')

The reason for such extensive usage of acronyms of foreign

${ }^{5}$ Nevertheless not every university has its Romanized and abbreviated form. Hanyang University (Kor. 한양대학교) or Osan University (Kor. 오산대학교) can serve as example here. The same applies to numerous government institutions. 
origin and the creation of new ones used mainly as proper names instead of their full versions in Korean, which are e.g. English translations of Korean names, could be the fashion for foreign languages especially English for political and economic reasons as well as a natural consequence of globalization and the growing need for the effective communication between Korea and the West.

Usually when talking about loanwords being used in the target language with a different writing system from the source one, the need of e.g. phonological or graphic adaptation is being referred to. Since Korean has its own alphabetic system one could presume that the first adaptation to go would be the graphic one. Meanwhile, the above-mentioned examples reveal that the adaptation of acronyms of foreign origin, which in fact can be treated as conventional loanwords to Korean writing system appears to be none. This results in using acronyms in their intact form as in English - their source language. Even though some acronyms do undergo graphic adaptation to Korean writing system, the abovementioned zero-adaptation appears to be more space-efficient, taking into account specific syllable structure of Korean (cf. e.g. IQ - Kor. 아이큐; two letters vs three syllables). Nevertheless as 'NATO' (Kor. 나토) or 'NASA' (Kor. 나사) show, Korean equivalent can be as long as the source acronym is (four letters or two syllables each). The situation of acronyms created on basis of English translation of Korean source forms is somewhat different since in many cases as e.g. in KDIA (Korean Defense Intelligence Strategy, Kor. 국방정보본부) Hangeul notation of the name, namely '케이디아이에이' is not used. KAIST however coming from 'Korea Advanced Institute of Science and Technology' is either referred to as '한국과학 기술원' or simply '카이스트'. The Korean name is obviously much longer than its acronymized form. Of course in order to find more accurate information on such proportions a statistical research would be needed. 


\subsubsection{Fields of Usage}

Acronyms became an inevitable necessity in various fields of contemporary civilization such as science and technology, economy, public life and politics. They are also present in widely understood mass media, marketing and commercials, military, geography, etc. Taking into account their extensive usage one can say that they became a part of the communication reality we live in and everything indicates that we cannot do without them. A few acronyms from the field of economy will serve as examples here.

(3.4) a) GDP (Gross Domestic Product) - Kor. 국내 총생산

b) GNP (Gross National Product) - Kor. 국민 총생산

c) KOSPI (Korea Composite Stock Price Index)

- Kor. 한국종합주가지수, 코스피 지수

\subsubsection{Conveyed meaning}

Acronyms used in Korean language regardless of their origin can designate various entities. Some of them are listed in the below ex. (3.5) (3.9).

(3.5) Names of countries ${ }^{6}$ :

a) ROK (Republic of Korea) - Kor. 대한민국

b) USA (United States of America) - Kor. 미국

(3.6) Names of companies, institutions and organizations:

a) KAL (Korean Air Lines) - Kor. 대한항공

b) KEB (Korea Exchange Bank) - Kor. 한국 외화 은행

${ }^{6}$ In 1977 Korea Press Foundation (Kor. 한국언론진흥재단) published a list of abbreviated forms of names of countries (and major cities) in order to systematize their notation. 
Anna BOROWIAK: On Some Properties of Acronyms...

c) MOE (Ministry of Education) - Kor. 교육부

d) KTF (Korea Telecom Freetel)

- Kor. 주식회사 케이티프리텔

(3.7) Professionalisms from various fields - mainly science, technology, medicine (Refer to examples given in the following section 3.1.4.)

(3.8) Job titles/ persons:

a) CEO (Chief Executive Officer) - Kor. 최고 경영자, 시이오

b) VIP (Very Important Person) - Kor. 요인, 귀빈, 비아이피

c) $\mathrm{MC}$ (master or ceremonies) - Kor. 사회자, 엠시

d) PD (producer) - Kor. 프로듀서, 피디

e) DJ (disk jokey, deejay) - Kor. 디제이

(3.9) Names of POP bands:

a) DMTN (Desire Motivation Timing Now)-Kor. 디엠티엔

b) GI (Global Icon) - Kor. 지아이

c) BTL (Beyond the Limit) - Kor. 비티엘

\subsubsection{Lexical familiarity}

Acronyms are shortened forms of commonly used names and expressions and as such are known by the general public, however a large number of them stay understandable only to specific communicative community. In the context of the language of the younger generation it is worth to mention intentional acronymization.

A wide knowledge of acronyms depends on the frequency of their usage especially in the context of country's development or endangerment - one can presume. That is why acronyms from science and hi-tech fields, on development of which South Korea places enormous importance, is not a surprise. Some of them such 
as HD-TV, UHD-TV, LED, LTE, GPS, PC, PDF, IQ, AIDS, SARS, MERS and many others function as proper nouns and are very well known to the general public presumably all around the world.

Nevertheless there is a considerable number of acronyms, which usage is limited to particular professions and thus stays understandable only to specialists from the fields in question. Those coming from military and medicine fields will serve as examples here.

(3.10) a) KADIZ (Korean Air Defense Identification Zone)

- Kor. 한국방공식별구역(韓國防空識別區域)

b) KAIS (Korean Air Intelligence System) ${ }^{7}$

- Kor. 한국공중정보체계

c) KCOIC (Korean Combat Operations Intelligence Center)

- Kor. 한국전투작전정보본부(韓國戰橱作戰情報本部)

(3.11) a) $\mathrm{ACH}$ (adrenocortical hormone) - Kor. 부신피질호르몬

b) ACP (Acyl-Carrier Protein) - Kor. 아실기 운반 단백질

c) REM (rapid eye movement) - Kor. 급속 안구 운동

d) $\mathrm{ME}$ (metabolized energy) - Kor. 변형된 에너지

\subsubsection{Method of formation}

Not every word which is spelled with capital letters and thus resembles an acronym really is one. In some words as in KIA (Kor. 기아), in the name of Korean popular singer 'PSY' or in the title of a song by EXO 'XOXO' meaning 'hugs and kisses' it appears that the capitalization was done deliberately in order to add unique character to words (or phrases) used as proper nouns.

Even though most of the acronyms used in Korean are true acronyms there are also examples like 'YTN' which can be treated

\footnotetext{
${ }^{7}$ KAIS however can also stand for Korea Advanced Institute of Science (Kor. 한국과학기술원).
} 
as a reverse acronyms or bacronyms. The above-mentioned 'YTN' was made on the basis of Yonhap Tongsin (Kor. 연합통신) meaning 'Yonhap News Agency', but its meaning can be interpreted as 'Yesterday, Today and Now' or 'Your True Network' - everything depends on what the current slogan of the agency is. Sometimes acronyms show author's creativity as in 'KOREA', which stands for 'Keep Optimistic Regardless of Every Adversity'.

A considerable number of newly coined names of Korean idol groups also confirms the undeniable influence that English has on Korean. Some of these names, as exemplified in the below ex.(3.12), can be treated as bacronyms.

a) H.O.T. (High-five Of Teenagers)

- Kor. 핫, 하이 파이브 오브 틴에이저스

b) M.I.L.K. (Made In Lovely Kin) - Kor. 밀크

c) N.EX.T. (New EXperiment Team) - Kor. 넥스트

One can presume that they are written with stops simply in order to distinguish them from already existing homonymic words since the great majority of acronyms used in Korean is written unstopped and without spaces (cf. paragraph 3.1.6.).

\subsubsection{Graphemic Form}

Graphemically Roman alphabet based acronyms usually consist of 2 to 5 letters, which are usually all capitalized and written without space or hyphen. They generally contain representation only for every autosemantic constituent (as in ex. 3.13). Although there are also some exceptions as in 'BEXCO' (Busan Exposition and Convention Center, Kor. 벡스코), where the last constituent, namely 'Center' is omitted or 'KOSPI' (Korea Composite $\underline{\text { Stock }}$ Price Index, Kor. 코스피지수), where the second constituent, namely 'Composite' is missing.

Sometimes the representation concerns also function words such as prepositions, conjunctions etc., as exemplified in the below 
ex. (3.13), although in most cases function words tend to be ignored and thus omitted. The underlined elements as in ex. (3.14) and (3.15) are not reflected in the acronymic formation.

(3.13) a) ROK (Republic of Korea) - Kor. 대한민국

b) MOE (Ministry of Education) - Kor. 교육부

c) MOU (Ministry of Unification) - Kor. 통일부

(3.14) a) KAIST (Korea Advanced Institute of Science and Technology) - Kor. 한국 과학 기술원, 카이스트

b) KISTI (Korea Institute of Science and Technology Information) - Kor. 한국과학기술정보원

c) SMOE (Seoul Metropolitan Office of Education) - Kor. 서울시 교육청

d) NPAD (New Politics Alliance for Democracy)

- Kor. 새정치민주연합

Apart from the above-mentioned examples, which consequently use or omit all synsemantic units while forming acronyms, there are also examples, which include only some of them. This phenomenon could be dictated by the convenience of pronunciation.

(3.15) a) MOTIE (Ministry of Trade, Industry and Energy)

- Kor. 통산업부

b) MOSF (Ministry of Strategy and Finance)

- Kor. 기획재정부

As exemplified above, acronyms used in Korean are usually unstopped and unspaced capital letters, regardless of the fact that in some cases grammatical words are unrepresented in the acronymic creation. Nevertheless on the basis of names of Korean popular music idol groups listed in the below ex.(3.16) and (3.17) or bacronymes illustrated in paragraph 3.1.5., one can confirm the existence of stopped formations as well. Among them are also examples where the stop is omitted after the last letter (as in ex. 
Anna BOROWIAK: On Some Properties of Acronyms...

3.17). One can presume that using stops is supposed to make the acronym look somewhat special, different from already existing e.g. SES meaning 'socioeconomic status' or milk - a common diary product.

(3.16) a) S.E.S. (Sea, Eugene, Sho) - Kor. 에스이에스

b) M.I.L.K. (Made In Lovely Kin) - Kor. 밀크

c) N.EX.T. (New EXperiment Team) - Kor. 넥스트

a) M.I.B (Most Incredible Busters) - Kor. 엠아이비

b) B.A.P (Best Absolute Perfect) - Kor. 비에이피

c) V.O.S (Voice of Soul) - Kor. 브이오에스

Writing some names with a colon as shown in the below ex. (3.18) - is also worth mentioning, since it differs from the above examples. Here the acronym is formed from the first syllable of each constituent forming the Romanized Korean name, which means that the acronym is not, as in other examples, the abbreviation of English name (translated into Korean) but the Korean one.

\section{(3.18) ZE:A (Children of Empire) \\ - Kor. 제국의 아이들 (jegugui aideul)}

Here however, only as far as ' $a$ ' - the the second part of the acronym is concerned there is no doubt as to Romanization, because Korean '아' is romanized into ' $a$ '. The first part may raise some doubts though since Korean '제' is not written as 'ze' by any of the most widely used Korean language romanization systems such as McCune-Reischauer Romanization, Revised Romanization of Korean (from 2000) nor Yale Romanization. According to the first system ' $ᄌ$ ' as an initial consonant is written as 'ch' (while final as ' $t$ '). The second one proposes to write the syllable-onset '大' as ' $\mathrm{j}$ ' (syllable-coda as ' $\mathrm{t}$ ') while the last system as ' $c$ '. Curiously enough in Yale Romanization ' $z$ ' appears. It is however used to write the Middle Korean letter ' $\Delta$ ' called bansiot (Kor. 반시옷) and not '즈.

Lee \& Ramsey (2000: 63) mention however that 'The 
affricates $c$, ch and $c c$ ('下', '天' and '不' respectively) are always palatalized (...) [and] since there is no $z$ in Korean, Koreans 'hear' English ' $z$ ' as /c/; thus Korean with insufficient mastery of English sounds pronounce English 'zoo' in a way that Americans hear as 'Jew'. The way in which Korean ' $丆$ ' is heard as English ' $z$ ' could be an explanation of ' $\mathrm{ZE}: \mathrm{A}$ 's name.

Apart from the above-mentioned formations there are also those written with a hyphen. K-POP from 'Korean POP' meaning 'Korean popular music' (Kor. 케이팝) can serve as an example here. Although K-POP is written with uppercase letters, nevertheless since its second component is a resultant form of back clipping of a word 'popular' used to describe the type of music, the formation has to be treated as a hybrid rather than a true acronym.

Besides K-POP there are also forms, which do resemble acronyms but are not them. This concerns internationalisms with a mixed structure (lower and upper case letters) such as $\mathrm{kW}$ (Kilowatt, Kor. 킬로와트) and MHz (megahertz, Kor. 메가헤르츠) as well as formations with numbers such as 4WD (four-wheel drive). This also concerns items such as KRW (Korean Won - Kor. 한화). All of them are just graphic shortenings read as full forms. That is why in this research - following Młodyński (1974) they will be considered abbreviations and not acronyms. Similar situation can be observed with partially acronymed names as in 'NH Bank' coming from 'Nunhyup Bank' (Kor. 농협은행), which also have to be treated as hybridal formations since the second part stays intact. ${ }^{8}$

It is worthwhile to notice that apart from the extremely numerous capitalized Roman alphabet-based formations there are also Hangeul-based examples, which as already mentioned, are referred to as 'East-Asian type of acronym[s]' (cf. Lee \& Ramsey, 2011) or 'syllable acronyms' (cf. 이재현, 2005: 382). Nevertheless their close resemblance to blends, caused by the lack of strict

\footnotetext{
${ }^{8}$ The same applies to a considerable number of Korean music band names created with numbers (e.g. B1A4 'One Blood Type B, Four Blood Type A' or 'Be the One, All for One' - Kor. 비원에이포, 4L 'Four Ladies' - Kor. 포엘, $2 \mathrm{AM}$ - Kor. 투에이엠, 2PM - Kor. 투피엠). They also have to treated as hybridal formation for the number is read in its full form.
} 
definitional criteria, makes it difficult to distinguish them in an unambiguous way. The lack of distinction between capital and lower case letters in Korean does not help the case either. Without a shadow of a doubt, the definite distinction between Hangeul syllable acronyms requires further research, nevertheless few examples analyzed as acronyms by the above-mentioned scholars will be given in the below ex. (3.19). The first two examples are forms abbreviated from compound nouns (written as one word), while the last two constitute noun phrases. It is also worth mentioning that all of them are in fact Sino-Korean words written in Hangeul.

a) 노조 (노동조합) - Eng. labor union (Hanja - 勞動組合)

b) 입시 (입학시험) - Eng. entrance examination (Hanja - 入學試驗)

c) 공위 (공동 위원회) - Eng. joint commission (Hanja - 共同委員會)

d) 노사 (노동자 사용자) - Eng. employee and employer (or 'labor and management', Hanja -勞動者 使用者)

\subsubsection{Type of founding Constituents}

Acronyms used in Korean can also be divided according to the properties their founding constituents have. Among them are letter acronyms (pronounced either as regular words or individual sounds), syllable acronyms and those of mixed structure. The examples of each type are given below.

(3.20) Letter acronyms pronounced as words

(also called orthoepic acronyms)

a) ROK (Republic of Korea) - Kor. 대한민국

b) MOE (Ministry of Education) - Kor. 교육부

c) MOTIE (Ministry of Trade, Industry and Energy)

- Kor. 통산업부 
(3.21) Letter acronyms pronounced as individual sounds (also known as alphabetizes)
a) IBK (Industrial Bank of Korea) - Kor. 기업은행
b) MBC (Munhwa Broadcasting Corporation)
- Kor. 문화방송
c) SBS (Seoul Broadcasting System) - Kor. 서울방송

(3.22) Syllable acronyms

a) COEX (Convention and Exposition)

- Kor. 코엑스, 종합 전시장

(3.23) Acronyms of mixed structure

a) BEXCO (Busan Exposition and Convention Center)

- Kor. 벡스코

b) POSCO (Pohang $\underline{\text { Steel Company) }}$

- Kor. 포스코, 포항제철의 개명

c) KOSIS (Korean Statistical Information Services)

- Kor. 국가통계포털

d) KOICA (Korea International Cooperation Agency)

- Kor. 국제협력단

e) KOSPI (Korea Composite $\underline{\text { Stock }} \underline{\text { Price Index }}$ )

- Kor. 한국 종합 주가 지수

f) KOSTAT (Korea Statistics) - Kor. 통계청

Apart from the above formations, there are some that can be perceived as hybrid compounds. One of them is very well known to the general public and thus frequently used 'SKY 대'. The word is a combination of an acronym built from the first letter of names of the three best universities in South Korea namely - Seoul National University, Koryo University and Yonsei University. The second part is a back clipping from daehakgyo (Kor. '대학교') meaning university. 
Anna BOROWIAK: On Some Properties of Acronyms...

\section{Concluding Remarks}

Despite the undeniable presence of acronyms in various aspects of everyday life, the subject of acronymy, which goes far beyond the morpheme-based mainstream word-formation, is not eagerly taken up and discussed by linguists - including Korean ones. Therefore finding an exhaustive analysis of acronyms in relevant literature is difficult.

The aim of this research was to identify, analyze and categorize acronyms used in Korean language. Although it was based on comparatively small dataset, it confirmed the existence of a considerable number of acronyms in Korean. Several criteria according to which they can be classified were proposed, namely: the origin, fields of usage, conveyed meaning and lexical familiarity, method of formation, graphemic form, and founding constituents. Since acronyms are items derived from written etyma rather than spoken ones, there was no need to divide them according to the criterion of spoken or written language as their source.

As far as the origin is concerned, the great majority are Roman alphabet based formations, which can be divided into the direct borrowings mainly form English and those coined in Korean, which are either English translations of Korean names or partially Romanized and partially translated names. Both of them reveal the changes in Korean lexicon influenced by the expansion of English lexicon, which is a consequence of globalization. There is also a group of Hangeul-based formations (Sino-Korean words), nevertheless due to their similarities to blends and the need for further study on them, they were presented in this research only in a very brief manner.

Taking into account the Korean writing system and its block-syllable structure, it is easy to presume that the acronyms of foreign origin, since written in linear order, were the first to be used before those coined in Korean. It is very unlikely that acronyms would be written in Korean alphabet (as they are in Latin) since Korean does not have ' $F$, V, Q' letters and such notation in Hangeul 
would make the communication ineffective. Acronyming the name of 'the Ministry of Trade, Industry and Energy' (MOTIE) to '모오 $\mathrm{E}$ 이 에' or its original Korean form tongsaneopbu (Kor. 통산업부) to ' $E$ 서어버' is technically possible although it would violate syllable structure, since Korean does not allow two consonants in syllable-onset, which means that only the last three letters would in fact form a syllable 'seop' (Kor. '섭'). This would result in a situation, where the first letter, namely ' $E$ ' not being a vowel and thus not having the ability to form a syllable would have to be left alone (cf. tseop, Kor.' $E$ 섭').

Even though in informal register of the language several frequently used formations resembling acronyms such as 'フ入, from '감사' meaning 'gratitude, appreciation, thanks' do exist, they have to be treated as abbreviations since they are nothing but orthographic abbreviations read as full forms. Nevertheless their existence reveals yet another dimension of the enormous influence that English has on Korean.

Semantically acronyms are distributed in various subject areas such as politics, economy, science and technology, medicine, geography, military etc. A great majority of them are the names of organizations of various kinds and professionalisms from various fields or disciplines. Usually when an acronym is used in Korean for the first time (except for the very well known ones) its full version is also given. However in many cases it is used along with Korean translation, which may appear inefficient.

As far as the lexical familiarity is concerned two groups of acronyms can be found, namely those known and used only by a specific communicative community such as students, professionals etc. and those, which are known and used by the general public (although there are also acronyms known by the general public yet used mainly by a specific milieu). Acronyms thanks to the tendency to form homonyms can be used as a kind of a password within a particular group. It especially concerns the language of the young generation.

As regards to the method of formation the overwhelming majority of acronym are here so-called true acronyms, even though 
some reverse acronyms were also found.

Graphemically Roman alphabet-based acronyms used in Korean generally consist of 2 to 5 letters, are written with capitals without periods and with no punctuation marks whatsoever. Although few examples confirm the existence e.g. of stopped formations, which are to help to differentiate the acronym from already existing homophones. Acronyms usually contain a representation for every lexical word while function words tend to be inserted for the pronunciation reasons.

A group of well-known and thus frequently used acronyms (without adaptation to Korean writing system) confirm, that the process of their assimilation is very advanced, if not finished. Despite the fact that in many cases Korean equivalent for the word does exist, for the sake of so-called language economy, only some of them are written in Hangeul, while a great majority is simply used in an intact form as a loanword and function as proper nouns, which means that they can take particles or create a hybridal phrases.

Even though this research discussed several properties of acronyms used in Korean it definitely did not exhaust the topic. Although the statistical research on acronyms has yet to be done, it is easy to notice that the number of acronyms in Korean grows with every year, that is why the subject definitely deserves greater attention. The author hopes to continue the research in due time.

\section{References}

Algeo, John. 1973. Acronyms (review). American Speech: 48: 3/4: 269-274.

Algeo, John. 1978. The Taxonomy of Word Making. Word: 29: 2: 122-131.

Algeo, John. 1980. Where All the New Words Come from? American Speech: 55: 4: 264-277.

Asher, R. E. \& Simpson, R. E. 1994. The Encyclopedia of 
Language and Linguistics. Pergamons Press. 80-82.

Bauer, Laurie. 1983. English Word-formation. Cambridge: Cambridge University Press.

Bauer, Laurie. 2001. Morphological Productivity. Cambridge: Cambridge University Press.

Baum, S. V. 1962. The Acronym, Pure and Impure. American Speech 37: $1: 48-50$.

Borowiak, Anna. 2015. On Some Selected Problems of Korean Abbreviology, International Journal of Korean Humanities and Social Sciences, Institute of Linguistics, Faculty of Modern Languages and Literature, Poznań: 1: 137-154.

Cambrigde Online

Dictionary.

http://dictionary.cambridge.org/grammar/british-grammar/wordformation (accessed 15-08-2014).

Collins

Online

Dictionary

http://www.collinsdictionary.com/dictionary/english/acron ymania (accessed 23-10-2015)

Cannon, Garland. 2011. Abbreviations and Acronyms in English WordFormation. American Speech 64: 2: 99-127.

Cassidy, Frederic G. 1993. Fifty Years among the new words (review). Linguistic Society of America: 69: 2: 397-400.

Choo, Miho and Kwak, Hye-Young. 2008. Using Korean, A Guide to Contemporary Usage. Cambridge: Cambrigde University Press.

Czarnecka, Anna \& Podracki Jerzy. 1995. Skróty i skrótowce pisownia, wymowa, odmiana i składnia. Oświata.

Dictionary.com

http://dictionary.reference.com/browse/acronym?s=t (accessed 22-10-2015)

Fandrych, Ingrid. 2008. Submorphematic elements in the formation of acronyms, blends and clippings. Lexical Submophemics: Lexis 2: 105-123. (online, accessed 10-102015).

Glowka, Wayne \& Lester Brenda K., Edge Constance. 1998. Among the New Words. American Speech: 73: 4: 421-441.

Heller, Louis G. \& Macris, James.1968. A Typology of Shortening Devices. American Speech: 43: 3: 201-208. 
Anna BOROWIAK: On Some Properties of Acronyms...

Kreidler, Charles W. 1978, Creating New Words by Shortening. (Paper presented at the Interdisciplinary Conference on Linguistics, Louisville, Kentucky, April 8 ${ }^{\text {n }}$ 1978.) (online accessed 20-102015).

Lee, Ikseop \& Ramsey, Samuel Robert. 2000. The Korean Language. New York: State University of New York Press.

Lee, Jin-sung. 2012. A Study of English Neologisms with Some Comparing Notes on Korean Neologisms. 한국사회언어학회. 사회언어학: 20: 2: 367-400.

Lee, Ki-Moon \& Ramsey, Samuel Robert. 2011. A History of Korean Language. Cambridge: Cambridge University Press.

Merriam-Webster Online Dictionary http://www.merriamwebster.com/dictionary/acronym (accessed 22-10-2015)

Młodyński, Józef. 1974. Stan badań nad skrótowcami. Poradnik Językowy 8: 407-16.

Młodyński, Józef. 1975. Klasyfikacja skrótów polskich. Poradnik Językowy 10: 546-53.

Müldner-Nieckowski, Piotr. 2007. Wielki słownik skrótów i skrótowców. Wrocław: Wyd. EUROPA.

Online Etymology Dictionary

http://www.etymonline.com/index.php?term=acronym\&all owed in frame $=0$ (accessed 22-10-2015)

http://www.nytimes.com/2002/02/24/magazine/24ONLANGUAG E.html (access 23-10-2015)

Oxford Dictionaries

Online

http://www.oxforddictionaries.com/definition/english/acro nymania (accessed 23-10-2015)

Podracki, Jerzy. 1999. Słownik skrótów i skrótowców. Warszawa: Wyd. Naukowe PWN.

Polański, Kazimierz (ed). 1999. Encyklopednia Językoznawstwa Ogólnego. Wrocław: Ossolineum.

Safire Wiliam. 2002. Acronymania. The New York Times (February 24th).(online, accessed 10-09-2015).

Song, Jea Jung. 2005. The Korean Language, Structure, use and context. London and New York: Routledge Taylor \& Francis Group.

Stockwell, Robert \& Minkova, Donka. 2001. English Words, History and Structure. Cambridge: Cambridge University Press.

Szadyko, Stanisław. 1997. Akronimy. Zeszyty Naukowe SGH 3: 116-30. 
고영근. 1991. 國語形態論研究. 서울: 서울 大學校出版部.

김정은. 2000. 국어 단어형성법 연구. 서울: 박이정.

김창섭. 1996. 국어의 단어형성과 단어구조 연구. 국어학총서 21. 서울: 태학사.

나찬연. 2007. 국어문법의 이해. 서울: 제이앤씨.

남기심, 고영근. 2006. 표준국어문법론. 서울: 탑출판사.

박경자, 임병빈, 김재원. 2001. 응용언어학사전. 서울: 경진문화사.

송철의. 2008. 한국어 형태음운론적 연구. 서울: 태학사.

시정곤. 1994. 국어의 단어형성 원리. 국학자료원. 언어학연구 12.

양주동. 1988. 현대국어대사전. 서울: 일중당.

이승희. 1955. 國語學概說. 民衆書館.

이승희. 1982. 국어대사전. 서울: 민중서림.

이우주. 2005. 영한 한영 의학사전. 서울: 아카데미서적.

이재현. 2005. 현대 국어의 축소어형에 관한 연구 -축소어형과

준말의 정의,축수어형의 조어법을 중심으로-.

한민족문화연구. 17: 376-399.

이지양. 1993. 國語의 融合現象과融合形式, 서울 大學校 大學院, 박사 학위 논문.

정희창. 2006. 준말의 단어 형성문제. 반교어문학회 21: 108-18.

최경은. 2005. 핸드폰 문자메시지(SMS) 언어의 특성과 전망. 독일언어문학 27: 1-16.

최규일. 2009. 한국어 어휘형성론. 제주: 제주대학교 출판부.

최현배. 1961. 우리말본. 서울: 정음문화사.

한국어언론진흥재단. 1977. 外來語 表記 統一案. 신문과 방송:

77 (online, accessed 12-10-2015)

홍순성. 1993. 준말의 형태적 유형. 韓國學論集 第二十輯, 12: 149-159.

황명권, 정도헌. 2011. 두문자어 지식베이스 자동 구축과 활용 방안. 한국정보기술학회 논문지. 9: 6: 167-176.

허웅. 1983. 국어학 - 우리말의 오늘. 어제 -. 서울: 샘문화사.

http://www.inven.co.kr/board/powerbbs.php?come_idx=2740\&l=4

99490 (accessed 8-10-2015)

http://news.chosun.com/site/data/html dir/2013/10/09/2013100903

297.html?Dep0=twitter\&d=2013100903297 (accessed 810-2015). 